\title{
Motivational Teaching Strategies within Saudi University EFL Classrooms: How to Improve Students' Achievement?
}

\author{
Seham Elashhab \\ Assistant Professor Applied Linguistics, Umm Al-Qura University, Saudi Arabia \\ saelashhab@uqu.edu.sa
}

DOI: https://doi.org/10.36892/ijlls.v2i1.173

$\begin{array}{ll}\text { Received: } & \text { Abstract } \\ \text { 30/1/2020 } & \text { Motivation is essential because it highly contributes to achievement. } \\ & \text { Teachers need to motivate their students in order to develop a positive } \\ \text { Accepted: } & \text { outcome. Research on motivation for foreign language learning has shown } \\ \text { 15/3/2020 } & \text { that teachers should be aware of their actions and behaviors in classroom } \\ & \text { because it is very likely that they can demotivate learners. This study } \\ \text { Keywords: } & \text { explores how motivational strategies used by English as a foreign language } \\ \text { Motivation; } & \text { (EFL) teachers could increase the motivation of students to learn English as } \\ \text { Strategies; } & \text { a foreign language. Participants included five EFL teachers along with one } \\ \text { Learning; } & \text { hundred first-year female students. The students completed a survey while } \\ \text { Language Teaching } & \text { the teachers took part in an interview. Both measures aimed to explore the } \\ & \text { attitudes of both teachers and students towards motivation in the foreign } \\ & \text { language classroom. Results showed that the most used motivational } \\ & \text { strategies were: resources that satisfy the students' needs and interests, } \\ \text { group work, active participation in class, and praises and rewards. The } & \text { findings of this study can contribute to teachers knowledge of the } \\ & \text { motivational strategies that work best for students especially those that are } \\ \text { pertinent to the Saudi context to improve their current teaching methods and } \\ \text { can contribute also to further research on motivation. }\end{array}$

1. INTRODUCTION

In the field of learning a foreign language, motivation is an essential factor. The need to motivate students can be considered more important than which curriculum is to be taught. Creating convenient environments for students to be motivated will help them achieve their long-term goals. Teachers' responsibilities include motivating their students through the use of appropriate strategies that could include: applying student-centered approach, relating the curriculum to the students' personal lives, implementing classroom activities that stimulate students' interest, and using authentic materials and technological aids.

Adopting motivational strategies in foreign language classes is a challenging task for teachers. As a strategy may work well with one group of students but not with another, and the long-term effect of this strategy may not be positive. Implementing motivational strategies that accommodate students learning styles can facilitate the language learning process and make it more productive and enjoyable. Teachers' role is critical as it depends on how they can effectively motivate the unmotivated students. The present study focuses on the positive effect of motivational strategies used by teachers to enhance Saudi students' motivation and achievement in English language classrooms. 


\section{LITERATURE REVIEW}

This section begins with an overview of how motivation is defined in the language learning context, followed by detailing methods for categorizing motivation: integrative and instrumental versus extrinsic and intrinsic. Then, I will review literature on the role of the teacher on enhancing learners' motivation inside the classroom and on the use of motivational strategies. Finally, the importance of motivational strategies in Saudi EFL classrooms is explained leading to the gap addressed in the present study.

\section{Defining Motivation}

A large volume of studies on L2 (second language) learning motivation is available. Motivation is a complex term. Many studies have been carried out to define and explain motivation in different ways, but all of them focused on the same main construct. Dörnyei (2001) defines it as the struggle to persist doing actions and to encounter any obstacles. Motivation is what makes actions continue. Supporting this definition, Harmer (2008) stated that what makes people achieve their goals are interior energies which he calls 'motivations'. This definition serves as the inside power that help people to reach their goals. Gardner (2007) also defined motivation as the incorporation of positive notions to learn another language with the power of achieving foreign language (FL) learning goals. These scholars defined motivation as the hidden need or desire to accomplish the target of language learning which explains peoples' behaviors for doing certain actions.

Furthermore, Graham and Weiner (1996) showed in their study that motivation is the reason behind peoples' actions and thoughts. This is an indication of how motivation can shape peoples' performance affecting the way the person thinks. In the same vein, Abrudan Caciora, (2008) added that motivation is the internal force that pushes one's actions. Motivation is what makes the purpose of the action maintained and stimulated. Thus, motivation is strongly linked to success in doing any activity. The more motivated the learner is, the more remarkable progress he will make. Motivation is the only reason for doing one activity with a high interest (Ames, 1990). All these broad definitions indicate the relationship between motivation and foreign language achievement. Motivation is considered one of the most important factors in second language acquisition (SLA) (Sun, 2010) because it is thought to determine the level of active personal involvement in language learning. Ultimately, all the above definitions embody the meaning of motivation that the current study would utilize in relation to motivational strategies in the FL classroom.

\section{Types of Motivations}

Motivation is the key to foreign language learning success, but not all learners can be motivated in the same way, for the same reason and have the same kind of orientation that express their goals (Rayan \& Edward, 2000). Motivations are categorized into four types. These are discussed in detail in this section.

\section{Integrative and instrumental motivation}

Integrative motivation refers to positive attitudes towards learning a second language (L2) in order to join and be part of another group or community who speaks that language. Instrumental motivation describes the beneficial systemic attainments that learners will accomplish from learning the L2. Integrative or instrumental motivations deal with the learner's direct (interaction) or indirect (getting a job) reasons for learning the target language 
(TL) (Dörnyei, 1994). For instance, when a learner wants to travel and interact with people of another culture and language, s/he is 'integratively' motivated. On the other hand, when the learner's goal is to get a better job, s/he is 'instrumentally' motivated.

Ribas (2009) argued that learners could have a combination of both types of motivation, as one may travel abroad to a society that speaks another language for a double goal, working and communicating with people from different cultures. A number of studies have provided support for the superiority of integrative reasons as they are fundamental factors to initiate actions. In contrast, in Arabic speaking countries where direct communication with native English speakers is not usually available, the sources of integrative motivation would be lower than those that trigger instrumental motivation.

\section{Intrinsic and extrinsic motivation}

Barker (2004) defined intrinsic motivation as the person's internal stimuli for doing something, while Harmer (2008) defined extrinsic motivation as the kind of motivation which is affected by outside conditions. Hence, a language learner who is intrinsically motivated would do the task with an internal interest and pleasure to satisfy their eagerness to learn the TL. However, extrinsically motivated learners are not self-determined, they pursue the task for instrumental reasons such as passing exams or getting a certificate (Eragamreddy, 2015; Lai, 2011). Harmer (2008) added that while intrinsic motivation is essential for L2 learning, extrinsic motivation can act as the outside support that stimulates the language learning process.

In conclusion, both taxonomies (integrative and instrumental versus extrinsic and intrinsic) are important in the current study. In fact, individuals who are intrinsically motivated complete L2 activities because they find them enjoyable. Hence, they are integratively motivated. On the other hand, those who are extrinsically motivated perform activities as they think that their contribution will lead to enviable results such as a reward, teacher admiration, getting a better job or prevention of punishment. So, they are instrumentally motivated (Hussain, 2018). Furthermore, intrinsic motivation is essential and fundamental for the integration process through which elements of one's existing internal awareness is assimilated with new knowledge (Mahadi \& Jafari, 2012). In contrast, Students who do not have instrumental or integrative motivation will face difficulties in learning a second language (Cook, 2000).

\section{The Teachers' influence on the learners' motivation}

Many factors play a vital role in shaping students' motivation to learn a foreign language. Dörnyei (2001) revealed that the most dominant factor affecting learners' motivation is the teacher's behavior. In addition, teachers have a crucial role to play in forming students' attitudes towards FL learning such as teacher's personality, feedback, appraisals and materials. Teachers can also help in stimulating students' desire to reach their goals in L2 learning. Teachers have various roles to play, and each role can inspire students' performance in different situations. Svobodova (2015) claims that students will have more opportunities to accomplish their learning goals as soon as they establish positive attitudes towards the FL. Dörnyei (2001) argues that the FL teacher is the only person who is responsible for engaging students in classroom activities through using suitable materials and by adopting a specific method for error correction that provides a positive reflection to students. This method does not interrupt students to correct mistakes and, thus, encourages the flow of speech and positively 
affect student's performance. Furthermore, teacher's support of the learning process has a powerful impact on learners' desire and motivation. Students would be more engaged and motivated if teachers showed more attention (Svobodova, 2015). A teacher is like an orchestra leader; if the crew (students) received his/her care, attention and support, the outcome would be astonishing. Therefore, Dörnyei and Yoshida (2011) discussed enthusiasm and good relationship between teachers and students as aspects of teacher behaviors that could strongly affect learner's academic motivation.

\section{Enthusiasm}

Al Kaboody (2013) stated that "enthusiasm is contagious in classrooms, if students recognize their teacher's enthusiasm to the task, they will be enthusiastic too" (p. 49). Particularly, students would appreciate the language learning process as teachers establish their excitement for the language through using authentic materials and real-life equipment that provide a cultural context of the TL (Wu \& Wu, 2008). According to Svobodova (2015), enthusiasm is a contemplative process; the more teachers are enthusiastic, the more learners will be motivated.

\section{Relationship with students}

Creating a good rapport with students has a strong impact on enhancing their motivation. The kind of relationship we are concerned with here is not only academic, but also personal through getting close to students and caring about them. Dörnyei and Yoshida (2011) claimed that students who are surrounded with their teacher's compassion, trust and attention have more opportunities to succeed in their academic performance than those who are not. When students are able to freely interact with teachers with no boundaries (but in respectful manners), their motivation to learn the TL is likely to improve.

\section{Motivation and language learning}

As discussed in the previous sections, motivation has the power to push learners towards FL achievement. Motivation is one of the factors that positively support success in language learning (Wu \& Wu, 2008; Wu, Yen, \& Marek, 2011; Csizer, \& Dörnyei, 2005). Further, Kassing (2011) argued that motivation develops learner's language competence and improves course grade. The relationship between motivation and FL learning has been the focus of research for a long time as motivation and language learning are two processes which seem to complement each other.

In addition, Gardner (2006) speculated that in the context of language learning and motivation, two types of motivations should be highlighted: language learning motivation and classroom learning motivation. He claimed that the first type is the general motivation that stimulates student to learn the TL, which occurs in any second language context in which language learning takes place, while the second type of motivation refers to specific classroom motivation. This latter type is a part of general language learning motivation that can be affected by many factors such as classroom environment, teachers and syllabus. Thus, without plenty of motivation, a perfect syllabus with a marvelous teaching environment cannot guarantee students' success in language learning. These claims emphasize the importance of motivation in a successful FL learning process. 


\section{The importance of motivational strategies in FL learning}

The importance of motivational strategies has been the focus of studies over the past decades. Teacher's success is usually measured by the effective use of such strategies to enhance students' performance. Bernaus, Willson and Gardner (2009) indicated that what takes place in the classroom can influence students' attitudes and motivation. Fernandez-Orio (2013) argued that teachers should utilize motivational strategies that are comparable with students' personal lives in order to help them in establishing positive attitude towards the TL and take part in classroom activities. Further, Dörnyei (2001) introduced a comprehensive framework presenting more than one hundred motivational strategies in a cyclic procedure. These can be divided into four dimensions: creating the basic motivational conditions, generating initial motivation, maintaining and protecting motivation and encouraging positive self-evaluation. These strategies are highly recommended by other researchers (Eragamreddy, 2015; Alqahtani, 2016) as applying them in language classrooms can enhance learners' performance. Dörnyei (2001) highlighted the influence of motivational strategies on students' performance and motivation. However, not every strategy works in every context.

Motivation, its types and theories have been the focus of extensive research, but only limited studies has covered motivational strategies used by EFL teachers in the classroom. Therefore, the current study attempts to help both EFL teachers and learners expand their understanding of motivational strategies in order to enhance EFL learning.

\section{EFL motivation research in Saudi Arabia}

There are various recent empirical studies on L2 motivation in the Saudi context that indicate a breakthrough in L2 motivation research in Saudi Arabia. One of these studies was conducted by Moskovosky and Alrabai (2009). Moskovosky and Alrabi (ibid) measured levels of intrinsic motivation of EFL learners in Saudi Arabia. They found their participants were aware of all the personal and professional benefits of learning English. They also indicated that Saudi learners are motivated by activities that give them high control and autonomy. Moskovosky and Alrabai (2009) also referred to the effect of the gender differences on motivational orientations. On the other hand, they showed that FL teaching was still a fairly teacher-centered process.

Another study by Alqahtani (2016) examined the effectiveness of some motivational strategies in enhancing the motivation of EFL Saudi learners. The study found a positive effect of teachers' motivational behaviors on enhancing the motivation of Saudi EFL learners. Furthermore, Alnatheers' (2013) study focused on how motivation and motivational strategies influence Saudi students' communicative competence. The results indicated that participants' communicative competence was significantly affected by motivation. However, teaching strategies supporting motivation did not directly affect students' communicative competence, but rather affected their motivation.

To sum up, various definitions of motivation from different perspectives focus on the same area of interest, that is, the internal desire a person has to do something (e.g., FL learning). Then, the above literature review detailed two motivational contrasts. The first type is integrative and instrumental motivation; learning a language for interaction with others or to get a job promotion. The second type is intrinsic and extrinsic motivation which deals with internal and external motives for FL learning. Later, a detailed elaboration of the most effective factors in learner's motivation has been provided. This is supervened by the relationship between motivation and language learning as overlapping processes that facilitate each other. 
Finally, the main concern of the present study has been discussed, that is, motivational strategies and their importance in EFL learners' achievement, particularly in the Saudi EFL context. The present study includes:

\section{Statement of the Problem}

One of the problems that first year students at a University in Saudi Arabia go through is lack of motivation to learn English language. This problem is due to lack of confidence, selfesteem and their negative attitude towards English language which requires professional help from their teachers through using the appropriate motivational strategies.

\section{Research Aims and Objectives}

The main purpose of this study is to investigate the motivational strategies used by EFL teachers to enhance students' performance in English and to motivate them to participate in the classroom. This study investigates the relationship between motivation and learning a foreign language. This study also examines a set of motivational strategies and students' attitudes towards them. Finally, this study sheds some light on the role of motivational strategies in improving classroom participation and language learning.

\section{Research Questions}

1. What are the motivational strategies employed by teachers in Saudi university EFL classrooms?

2. Which motivational strategies undergo major changes through the process of learning?

3. Which motivational strategies do teachers identify as the most important ones and how/ when are they used?

\section{Significance of the Study}

This study emphasizes the importance of using motivational strategies by EFL teachers in their classes to develop students' abilities in both learning English inside the classroom and using it in their real life. By adopting appropriate motivational strategies in EFL classes, students would make a noticeable progress in learning the four language skills of reading, writing, listening and speaking. This paper provides important insights based on empirical data tackling both teachers and students' use of and perceptions of a set of motivational strategies in the Saudi university EFL classroom context as a way to facilitate teaching English in Arabic speaking countries.

\section{METHODOLOGY}

This study focuses on the teachers' use of motivational strategies to enhance EFL learners' motivation and classroom participation. This section demonstrates the instruments through which the data was collected: questionnaires and interviews. Collecting different types of data using different methods from various sources provides a rich contextual basis for interpreting and validating the results.

\section{Procedures}

During the questionnaire process, the English language teachers of the targeted groups were first contacted face- to- face in order to introduce the questionnaire and gain approval to 
recruit their students as participants. The questionnaire was then sent to students enrolled in the English course within the chosen groups. A cover letter was attached to the questionnaire to introduce the researcher, the objectives of the study and the significance of the survey. For ethical purposes, prior to the administration of the questionnaire, students were provided with information regarding all aspects of the research project including its objectives and its benefits to them and to future students. Those who were not interested in participation had the choice to withdraw (and some of the students did).

The questionnaire was emailed to students with enough instructions about how to complete it. Furthermore, teachers of the targeted groups were aware of all the study procedures from the questionnaire design to administration. This was due to several discussions which were maintained in the shared teachers' office in which the researcher explained the framework and the categorization of the motivational strategies. Thus, the researcher and all participating teachers shared the same concepts of the motivational strategies implemented in the current study. These procedures were followed precisely to elicit accurate and useable data.

\section{Participants}

Participants of this study were one hundred female university students from five groups studying in the second semester of the first year (preparatory year) at a University in Saudi Arabia. All students completed the Oxford Placement Test (https://www.oxfordenglishtesting.com/DefaultMR.aspx?id=3034\&menuId=1) to be placed in different language levels. These groups were randomly selected and they are all high intermediate EFL learners taking ESP courses related to their future studying areas of business administration, computer science and general science. The sampling criteria included gender (all female), age (ranged from eighteen to twenty), language level (high intermediate), the education system through which they were exposed to English and interest in participating in the study. All participants graduated from Saudi high schools. Additionally, the five teachers of these groups were interviewed. These EFL teachers are specialized in teaching English at the English Language center (ELC) of Umm Al-Qura University in Saudi Arabia.

\section{Instruments}

The research approach employed was a mixed method design, using qualitative and quantitative data.

\section{Questionnaires}

Questionnaires were used to obtain quantitative data from a large group of EFL female learners. The questionnaire of this study consists of 15 items designed based on a number of research studies as they offer a detailed framework of motivational strategies for foreign language classrooms, such as, Gardner, (2006 and 2007), Cheng and Dörnyei, (2007), Alnatheer (2013) and Gulloteaux \& Dörnyei, (2008). The questionnaire had 15 items divided among several categories: perceived communication, integrativeness, attitudes toward the learning situation and the target language, teachers' communicative style, and language class activities.

This instrument used with first year university female students to investigate their views about the motivational strategies used by their EFL teachers in order to improve the students' achievement. The questionnaire packages (a cover letter explaining the purposes and benefits 
of the survey, and a set of questions) were sent by email to Saudi students enrolled in English language program of Umm Al-Qura University. 130 questionnaires were distributed and 108 were returned. 8 questionnaires were excluded from the analysis, due to significant incompletion. As a result, 100 valid responses remained.

\section{Interviews}

The researcher conducted face to face structured interviews to figure out any misunderstanding between the questions and responses of both teachers and the researcher. The interviews were conducted with five teachers, teaching the same participated sample of students, for the purpose of getting more details about the importance of motivational strategies and how they are implemented in the EFL classroom. The interviews consist of six questions that are well-structured and no more questions were asked. The answers were noted down.

\section{RESULT}

For the interviews, the researcher pointed out teachers' comments and opinions, which are presented in table (2) below. For the questionnaires, the obtained data were analyzed statistically using Microsoft Excel and were presented in table (1) and figure (1) below.

Table 1 and Figure 1 illustrate all of the 15 questionnaire responses:

\section{Table 1. Number of students' responses in the 15 questionnaire questions and their average}

\begin{tabular}{|c|c|c|c|c|c|c|}
\hline$\#$ & Motivational strategy Statements & SA & A & $\mathrm{N}$ & $\mathrm{D}$ & SD \\
\hline 1 & The English teacher presents materials in an interesting way. & 80 & 20 & & & \\
\hline 2 & $\begin{array}{l}\text { The teacher chooses topics that she thinks are relevant to } \\
\text { students' lives. }\end{array}$ & 20 & & & & 80 \\
\hline 3 & The teacher does not always follow the text book. & & 80 & 20 & & \\
\hline 4 & $\begin{array}{l}\text { The teacher gives everyone a turn to speak in order to check } \\
\text { students' understanding. }\end{array}$ & & & & 20 & 80 \\
\hline 5 & $\begin{array}{l}\text { The teacher addresses questions to the whole class rather than to } \\
\text { selected individuals. }\end{array}$ & 72 & 28 & & & \\
\hline 6 & $\begin{array}{l}\text { The teacher gives students enough time in class to practice their } \\
\text { English language. }\end{array}$ & & 20 & & 60 & 20 \\
\hline 7 & The teacher provides positive feedback. & 60 & & 40 & & \\
\hline 8 & The teacher adopts a friendly, non-authoritarian manner. & 68 & & 32 & & \\
\hline 9 & It is better to receive feedback from my classmates and teacher. & 80 & 20 & & & \\
\hline 10 & The teacher encourages students to play speaking games in class. & 12 & & & 20 & 68 \\
\hline 11 & $\begin{array}{l}\text { The teacher gives students good reasons for why a specific task } \\
\text { is meaningful. }\end{array}$ & 64 & & & 36 & \\
\hline 12 & $\begin{array}{l}\text { The teacher creates a supportive classroom environment so } \\
\text { students would take risks. }\end{array}$ & & & & 16 & 84 \\
\hline
\end{tabular}


13 The teacher allows students to choose topics for conversation and videos for discussion.

14 The teacher supplements the students' textbook with visual $24 \quad 76$ materials from the internet.

15 The teacher monitors students' progress and celebrates their $80 \quad 20$ victories

\begin{tabular}{|ccccccc|}
\hline Total number of responses & 456 & 168 & 92 & 256 & 528 \\
\hline Average & 57 & 33.6 & 30.6 & 36.57 & 66 \\
\hline Mean & 66 & 20 & 32 & 24 & 78 \\
\hline
\end{tabular}

Note: $(\mathrm{SA})=$ strongly agree, $(\mathrm{A})=$ agree,$(\mathrm{N})=$ neutral,$(\mathrm{D})=$ disagree and $(\mathrm{SD})=$ strongly disagree .

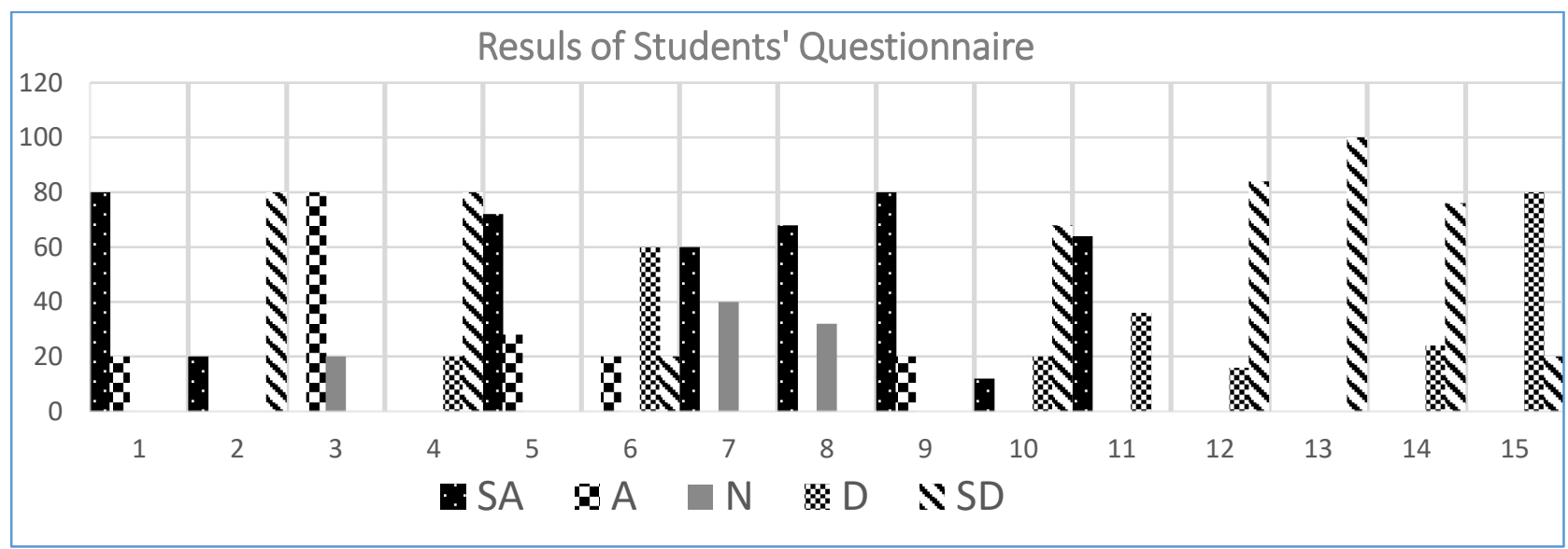

\section{Figure 1. Results of Students' Questionnaire}

Figure 1 indicates that 80 students out of $100(80 \%)$ strongly agreed that their teacher introduced materials in an interesting way while 20 students $(20 \%)$ showed less agreement with the way their teacher presented the teaching material to them.

Concerning the second item of the questionnaire, 20 students $(20 \%)$ totally agreed that their teacher cared to bring topics which are relevant to students' personal lives. On the contrary, 80 students $(80 \%)$ expressed a strong disagreement regarding this point.

Looking at the third item, it is clear that 80 students $(80 \%)$, who are the majority, strongly agreed that the teacher used only the textbook, while 20 students $(20 \%)$ expressed neither agreement nor disagreement (i.e., were neutral) regarding the teacher's use of textbook only.

The results of Item 4 demonstrate that 20 students (20\%) showed disagreement about the teacher's way of giving each student a turn to speak whereas 80 students (80\%) strongly disagreed that the teacher ensures a chance for each student to speak in order to check their understanding.

Results of Item 5 present that 72 students (72\%) strongly agreed that the teacher discussed questions with the whole class and not individually. In contrast, 28 students (28\%) agreed that the teacher asked questions publically in the class. 
Results of Item 6 shows that 20 students (20\%) strongly agreed that teacher gave sufficient time for students to practice their English language in the class while 20 students (20\%) strongly disagreed that they got enough time to use their English language in the class. These two groups of students are coupled with another group of 60 students (60\%) who disagreed with this statement.

Item 7 results show that 60 students $(60 \%)$ strongly agreed that their teacher provided positive feedback. However, 40 students $(40 \%)$ were in the middle of the road in terms of teacher's giving of positive evaluation.

Results of Item 8 demonstrated that 68 students (68\%) strongly agreed that the teacher's manner supported flexibility. On the other hand, 32 students $(32 \%)$ were neutral regarding that point.

Regarding Item 9 results, 80 students (80\%) strongly agreed that receiving feedback from both teacher and classmates was more effective. Then, again 20 students (20\%) agreed that it was better to have feedback from both.

Item 10 results showed that 68 students (68\%) highly disagreed that the teacher encouraged speaking activities inside the classroom. Moreover, 20 students $(20 \%)$ indicated their disagreement than the previous group. This was unlike the rest 12 students (12\%) who strongly agreed that the teacher inspired them to have speaking games during the class time.

Results of Item 11 illustrated clearly that a great portion of students (64\%) firmly agreed that the teacher explained the significance of any task. However, 36 students (36\%) disagreed that the teacher provided a rationale for doing the task.

Concerning results of Item 12, 84 students (84\%) strongly disagreed that the teacher helped students to tackle difficulties by establishing a supportive classroom while 16 students (16\%) disagreed with the statement claiming that the teacher did not create a supportive classroom so students could take risk.

Responses to Item 13 showed that all students $(100 \%)$ strongly disagreed that the teacher gave students opportunity to select topics for classroom discussion.

Results of Item 14 indicated that more students (76\%) showed their strong disagreement that the teacher's role was to discover students' needs to involve them into the course in comparison to those $(24 \%)$ who disagreed with this statement.

Item 15 results showed that 80 students $(80 \%)$ of the students disagreed that the teacher kept track of their development and praised their achievement. On the other hand, 20 students (20\%) strongly disagreed that the teacher followed their progress and celebrated their success.

\section{The interview included the following questions:}

Q1. Do you think it is important to use motivational strategies to develop students' motivation?

Q2. What do you think are the most important motivational strategies, especially in the context of EFL?

Q3. How can you keep your students motivated during the class or during a task?

Q4. Tell me about motivated class, what do you do to keep your students motivated at the end of the lesson or task?

Q5. Now, tell me about de-motivated class, what do you do to encourage students' motivation?

Q6. Do you have anything to add? 
Table 2 below summarizes the responses of the five teachers.

Table 2. Results of Teachers' Interviews

\begin{tabular}{|c|c|c|c|c|c|c|c|}
\hline \multirow[t]{2}{*}{ No } & \multicolumn{2}{|c|}{ Q1 } & \multirow[t]{2}{*}{ Q2 } & \multirow[t]{2}{*}{ Q3 } & \multirow[t]{2}{*}{ Q4 } & \multirow[t]{2}{*}{ Q5 } & \multirow[t]{2}{*}{ Q6 } \\
\hline & Yes & No & & & & & \\
\hline $\mathrm{T} 1$ & $\mathrm{Y}$ & & $\begin{array}{l}\text { No fixed } \\
\text { strategy, } \\
\text { multiple, } \\
\text { raise } \\
\text { culturally } \\
\text { related issues } \\
\text { for } \\
\text { discussions } \\
\text { such as } \\
\text { talking about } \\
\text { food or } \\
\text { celebrations }\end{array}$ & $\begin{array}{l}\text { Ask question, } \\
\text { give positive } \\
\text { feedback, move } \\
\text { around the class, } \\
\text { eye contact and } \\
\text { give } \\
\text { encouragement } \\
\text { comments, put } \\
\text { marks for class } \\
\text { participation }\end{array}$ & $\begin{array}{l}\text { Peer } \\
\text { evaluation, } \\
\text { summary, } \\
\text { review the task } \\
\text { and put a } \\
\text { conclusion or } \\
\text { summarize the } \\
\text { text or the } \\
\text { lesson, } \\
\text { group } \\
\text { competitions }\end{array}$ & $\begin{array}{l}\text { Eye contact, } \\
\text { ask questions, } \\
\text { Convince } \\
\text { learners that } \\
\text { English is a } \\
\text { prestigious } \\
\text { language, } \\
\text { group } \\
\text { competitions }\end{array}$ & $\begin{array}{l}\text { I tell my students } \\
\text { that they will } \\
\text { impress people } \\
\text { and friends if they } \\
\text { use English words } \\
\text { in their } \\
\text { communication } \\
\text { outside the } \\
\text { classroom }\end{array}$ \\
\hline $\mathrm{T} 2$ & $\mathrm{Y}$ & & $\begin{array}{l}\text { Through } \\
\text { translation }\end{array}$ & $\begin{array}{l}\text { Ask questions, } \\
\text { listening } \\
\text { materials }\end{array}$ & $\begin{array}{l}\text { Summary, } \\
\text { reinforcement- } \\
\text { practice }\end{array}$ & Ask questions & $\begin{array}{l}\text { Motivation is the } \\
\text { base of language } \\
\text { learning }\end{array}$ \\
\hline $\mathrm{T} 3$ & $\mathrm{Y}$ & & $\begin{array}{l}\text { Be good with } \\
\text { students }\end{array}$ & $\begin{array}{l}\text { Interaction } \\
\text { Pair/group work }\end{array}$ & $\begin{array}{l}\text { Ask questions, } \\
\text { team } \\
\text { competitions }\end{array}$ & $\begin{array}{l}\text { Discussions of } \\
\text { students' } \\
\text { related topics }\end{array}$ & No \\
\hline $\mathrm{T} 4$ & $\mathrm{Y}$ & & $\begin{array}{l}\text { Materials } \\
\text { related to } \\
\text { personal } \\
\text { lives }\end{array}$ & $\begin{array}{l}\text { Various } \\
\text { activities, group } \\
\text { discussion, } \\
\text { discussions as a } \\
\text { whole class }\end{array}$ & $\begin{array}{l}\text { Conclude, sum } \\
\text { up, recap the } \\
\text { reading or } \\
\text { listening task } \\
\text { could maintain } \\
\text { the attention } \\
\text { and focus }\end{array}$ & $\begin{array}{l}\text { Ask } \\
\text { question- } \\
\text { provide a } \\
\text { focus, raising } \\
\text { interesting } \\
\text { topics }\end{array}$ & $\begin{array}{l}\text { Motivation is } \\
\text { important in the } \\
\text { learning process }\end{array}$ \\
\hline T5 & $\mathrm{Y}$ & & $\begin{array}{l}\text { Pair work- } \\
\text { discussion- } \\
\text { multiple } \\
\text { topics not } \\
\text { only one }\end{array}$ & $\begin{array}{l}\text { Work together, } \\
\text { listen to } \\
\text { students' } \\
\text { opinions }\end{array}$ & $\begin{array}{l}\text { Review the } \\
\text { task and put a } \\
\text { conclusion or } \\
\text { summarize the } \\
\text { readings }\end{array}$ & $\begin{array}{l}\text { Not to } \\
\text { memorize- } \\
\text { opinions by } \\
\text { using words }\end{array}$ & No \\
\hline
\end{tabular}

Concisely, Table 2 shows that all five teachers agreed on the same answer for Question 1, that is, "YES". Conversely, for the second question, there were various answers (different strategies) and both T1 and T5 were fairly similar in their interpretation. In Question 3, teachers' comments varied according to their experience. Similarly, responses to Question 4 clearly identified that most of teachers' perceptions were closely related. Additionally, Question 5 illustrated that the "ask-question" strategy was the most common reply for the interviewed teachers. However, T3 utilized different activities (i.e., discussions of topics that interest her students) to motivate the class. In the final analysis of the last question (\#6), one teacher connected FL use with prestige by encouraging her students to use English words 
during their Arabic language communication with friends; two teachers indicated that motivation is very important for language learning; while the other two teachers did not add anything regarding motivation.

In conclusion, classroom strategies applied by the language teachers are quite crucial in raising the morale, motivation and attitude of the learners towards the target language. The results of this study showed that the most used motivational strategies were: resources that satisfy the students' needs and interests, group work, active participation in class, and praises and rewards. The teachers' main aim was to increase the students' interest, attention and satisfaction by applying effective motivational strategies.

\section{DISCUSSION OF THE RESULTS}

In general, the outcomes of students' questionnaires demonstrate their views regarding how important motivational strategies are for their learning progress. Most of the students revealed either their strong agreement or strong disagreement towards teachers' use of motivational strategies. While a small percentage of students preferred to stay in the middle of the argument. This may be driven by their unawareness of the actual implication of these strategies.

\section{Students' Questionnaire Items:}

1- The English language teacher presents materials in an interesting way.

The results of this item indicate students' strong agreement, which shows the strong influence of this strategy on their motivation in the classroom. Fernandez-Orio (2013) states that if the teacher is knowledgeable enough about his/her students' interest, they simply will be able to present materials in an interesting way as students' curiosity will be raised. Dörnyei (2001) also added: "I have found that the way we present tasks can make a huge difference in how students perceive and approach them" (p. 78).

2- The teacher chooses topics that she thinks are relevant to students' lives.

The importance of personalizing topics to students' own lives were clearly established by the majority of students' responses. This seems to agree with Dörnyei's (2001) claim that teachers have no chance to make the materials personally related to the students' lives. It is important to realize here that the context of this study is what Dörnyei (ibid) was referring to as teachers having to cover a detailed pacing guide.

3- The teacher does not always follow the textbook.

Students' responses for this item showed a clear sign for agreement. Most students (80\%) shared their agreement but only (20\%) of students were neutral. This gives a reason for students' high expectations of the teacher not sticking to the syllabus.

\section{4- The teacher gives everyone a turn to speak so that she can check students' understanding.}

Through the gathered data about this item, the percentage of opposition by students was high. This percentage clearly indicates the passive role students play in speaking classes compared with their teachers. This is mainly due to a teacher-centered in contrast with a student-centered approach. 
5- The teacher addresses questions to the whole class rather to selected individuals. Most students agreed with this statement. This obviously reflects the sheltered feeling that students have when they work in groups. Indeed, this has been also emphasized in Social Psychology as it brings benefits to the whole group. According to results of Kassing's (2011) study, group or pair work has many advantages for students since the group as a social unit exerts a powerful influence on its members' behaviors.

6- The teacher gives students enough time in class to practice their English language. The conclusive results of students' opinions were completely dissatisfying as (20\%) of students agreed as opposed to $80 \%$ who expressed their disagreement. This may stem from the regular short class time and the restricted number of curricula that teachers need to cover. Also, priority might be given to score achievement rather than language achievement.

\section{7- The teacher provides positive feedback.}

With reference to feedback, students' responses varied between strong agreement $(60 \%)$ and neutrality $(40 \%)$. This clearly illustrates how much the way of feedback delivery matters to students. These results are in line with Shousha's (2018) recommendations to teachers that in order to enhance Saudi students' motivation, positive feedback should be provided to increase their self-beliefs of well doing.

\section{8- The teacher adopts friendly, non-authoritarian manner.} A great number of students showed a strong agreement $(68 \%)$ with respect to this item while the others were neutral $(32 \%)$. This could be affected by students' good relationship with teachers. As it was indicated in the literature review, it is important for teachers to establish good rapport with students to increase their motivation.

9- It is better to receive feedback from my classmates and teacher.

The obtained data about this item shows that students showed agreement with this statement as they preferred to be assessed by both colleagues and teachers. This is because it helps them in being evaluated from different perspectives and reduces the embarrassment of making mistakes in front of the class.

10- The teacher encourages students to play speaking games in class. Most students expressed disagreement (D 20\% \& SD 68\%) while only (12\%) of students showed agreement. This distinction may show us students' different learning styles and inappropriate teaching methods used by their teachers.

11- The teacher gives students good reasons as to why particular task is meaningful. Explaining the rationale behind each task for students will help students value the purpose for which it has been conducted (Dörnyei, 2001). The percentage of students who indicated their agreement (64\%) was higher than those who disagreed (36\%). These responses are similar to Cheng and Dörnyei's (2007) survey results on Taiwanese learners, which revealed that communicating an appropriate rationale and strategic advice, is endorsed by Taiwanese English teachers. They considered it as an essential ingredient for motivating EFL learners.

12- The teacher creates supportive classroom so students will take risks. 
All activities that happen in the classroom could enhance students' motivation (Bernaus, Wilson, \& Gardner, 2009). Although this might be true, the results that accrued from this item were entirely different as students mostly disagreed. In reality, elements that slow down students' motivation are related to language learning anxiety that is created by unpleasant atmosphere in the classroom.

13- The teacher allows students to choose topics for conversations.

All of the students' responses were in strong disagreement $(100 \%)$, which is brought by teachers' control over the classroom goals and instructions. In contrast, a study conducted by Mart (2011) suggested a number of motivational strategies to be considered when planning lessons such as giving students options in the classroom, helping students to be autonomous learners and improving skills of self-directed learning.

\section{4- Find out students' needs and build them into the course.}

In order to engage students in the classroom, the course needs to be as relevant to them as possible. But results of the present study seem to suggest that students were taught courses that do not serve their needs as all of them disagreed with this item. However, researchers emphasize this issue arguing that if students sensed that the teacher does not care about their needs, their motivation would be undermined.

\section{5- Monitor students' progress and celebrate their victories.}

Most students disagreed with this statement (80\%). This may suggest that students strongly need teacher's guidance and support. Sources of such a response might be teachers' low levels of concern with their students' achievements.

\section{Teachers' Interview Questions:}

Teachers' answers and comments were sorted by similarities and differences, according to their experiences.

Q1- Do you think it is important to use motivational strategies to develop students' motivation?

"Yes", was the standard answer among all five teachers, through which they emphasized the importance of implementing motivational strategies inside the classroom as they play a vital role in stimulating students' progress. This finding goes in line with findings of previous studies that shed light on motivation and how it may strengthen Saudi students' achievements (Alnatheer, 20013; Shousha, 2018).

Q2- What do you think are the most important motivational strategies in the context of EFL teaching?

Teachers did not highlight any fixed strategies to be followed inside the classroom. This diversity was justified by most teachers as it depends on the context in which the strategy takes place. Comparatively, these findings were considered by Cheng and Dörnyei (2011) as they formulated ten motivational strategies and concluded that these may not be efficient in every cultural context. Interestingly, that was what two teachers suggested "be good with students, personalize the material and discuss culturally related issues". This suggestion is further illustrated in students' preference for these strategies as evident in the questionnaire results. 
Q3- How can you keep your students motivated during the task?

Teachers recommended several techniques in order to maintain students' motivation during the classes. The most common strategies stressed by teachers were: listen to students' opinions, ask questions and interaction. This manifested enthusiasm towards keeping students engaged to establish motivated classes. These suggestions are in the same line with Dörnyei and Yoshida's (2011) cautions that "natural tendency to lose sight of the goal, to get tired or bored of the activity, and to give way to attractive distractions or competing action tendencies will result in initial motivation gradually petering out" (p. 118).

Q4- Tell me about motivated classroom what do you do to keep your students motivated at the end of the task or lesson?

It is speculated that increasing students' motivation is useless without being able to keep it in the classroom. What teachers declared to do in order to hold students' motivation till the end of the lesson included focusing on summarizing strategies which can help students remember what the lesson was about. Also, teachers placed emphasis on reinforcement, peer evaluation and praise strategies because of their positive effect on students' motivation. Similarly, Dörnyei (2001) suggested that in order to improve students' self-confidence, teachers need to provide praise and reinforcement. Students' progress in the target language can be enhanced as soon as they have their teacher's support and encouragement.

Q5- Now, tell me about de-motivated classroom, what do you do to encourage students' motivation?

Numerous strategies had been implemented by teachers to stimulate students' motivation in the classroom. These include eye contact, asking questions, debating, competitions, assigning marks for classroom participation, and giving opinions in their own words. Nhem (2019) assumes that these social strategies have been highly preferred by different groups of students in diverse educational settings when it comes to learning English language.

Most teachers had something in common about the given strategies: they carefully considered the context which determined the effectiveness of one strategy over another. Interestingly, one teacher connected English language use to prestige and high social class. This gives credit for teachers to choose their strategies that are consistent with their classroom environments and students' needs and mentality. Finally, certain teachers added that motivation is essential in language learning, and that it is the base of the language process. This claim has previously been raised by several researchers (Alnatheer, 2013; Dörnyei, 2001; 2011; Ribas, 2009; Shousha, 2018; Svobodova, 2015).

\section{CONCLUSION AND PEDAGOGICAL IMPLICATIONS}

The purpose of this study was to investigate the role of the teachers' motivational strategies in improving Saudi students' motivation in the FL classroom. With the help of questionnaires and interviews, data was collected from both students and teachers. The findings showed that both teachers and students value motivation and are concerned with how it can be improved. Although their attitudes toward some motivational strategies seemed to be similar, differences were found in terms of ranking these strategies. Finally, the students' preference for teachers' use of motivational strategies was clearly evident, which is a clear indicator that 
motivation could be the base for a successful EFL learning process. Students highly value the strategies that are relevant to their life.

The researcher suggests that teachers need to bear in mind that every action from a student in the classroom is highly affected by his/ her motivation. If students lack motivation, they will lack interest in the whole learning process. Therefore, teachers' use of motivational strategies must suit the classroom atmosphere and the students' needs and mentality. As students highly value the strategies that are relevant to their life, the researcher recommends that EFL teachers should create a motivated classroom environment through engaging their students in different tasks. This also helps students to overcome their shyness and fear of communicating in a new language. Motivated classroom atmosphere also provides opportunities for students to speak regularly in the target language as it aims at cultivating confidence, competence and autonomy.

\section{REFERENCES}

Abrudan Caciora, S.V, (2008). Motivation in Language Learning. Annals of the University of Oradea, Economic Science Series, 17(1), 557-562

Al Kaboody, Mastoor. (2013). Second Language Motivation; The Role of Teachers in Learners' Motivation. Journal of Academic and Applied Studies, 3(4), 45-54.

Alnatheer, A. (2013). The role of motivation and motivational strategies in Saudi students' communicative competence in English. PhD thesis, Queensland University of Technology.

Alqahtani, S. (2016). Motivational Strategies and EFL Teachers' Perceptions: A Saudi Survey.

Theory and Practice in Language Studies, Vol. 6(4), 663-674. Doi: http://dx.doi.org/10.17507/tpls.0604.02

Ames, A. C. (1990). Motivation: What teachers need to know? Teachers College Record, 91, 40921

Barker, S. (2004). Psychology (2nd Ed.). Boston: Pearson Education.

Bernaus, M., Wilson, A. \& Gardner, R. (2009). Teachers' motivation, classroom strategy use, students' motivation and second language achievement. Porta Linguarum, 12, 25-36.

Cheng, H.F., \& Dörnyei, Z. (2007). The use of motivational strategies in language instruction:

The case of EFL teaching in Taiwan. Innovation in Language Learning and Teaching, 1, 153-73. http://dx.doi.org/10.2167/illt048.0

Cook, V. (2000). Second language learning and language teaching. Beijing: Foreign Language Teaching and Research Press and Edward Arnold Publishers Ltd.

Csizer, K., \& Dörnyei, Z. (2005). Language learners' motivation profiles and their motivated learning behavior. Language Learning, 55, 613-159. https://doi.org/10.1111/j.0023$\underline{8333.2005 .00319 . x}$

Dörnyei, Z. (1994). Motivation and motivating in the foreign language classroom. Modern Language Journal, 78, 273-284. http://www.jstor.org/stable/330107 
Dörnyei, Z. (2001). Motivation and Second Language Acquisition. Honolulu: University of Hawai'i Press

Dörnyei, Z., \& Ushioda, E. (2011). Teaching and researching motivation. Harlow: Pearson Education.

Eragamreddy, N. (2015). Motivating learners to learn: Libyan EFL teachers' strategies and a perspective. International Journal of English Language \& Translation Studies, 3(2), 42-54. DOI: $10.5281 /$ zenodo.34367

Fernandez-Orio, S. (2013). Motivation and Second Language Acquisition. La Rioja: Universidad de la Rioja Publications.

Gardner, R. C. (2006). The socio-educational model of second language acquisition: A research paradigm. In S. H. Foster-Cohen, M. M. Krajnovic \& J, M. Djigunovic (Eds.),

Annual conference of the European second language association. Amsterdam: Benjamins. https://doi.org/10.1075/eurosla.6.14gar

Gardner, R. C. (2007). Motivation and second language acquisition. Porta Linguarum, 8, 9-20.

Graham, S., \& Weiner, B. (1996). Theories and principles of motivation. In D. C. Berliner \& R. C. Calfee (Eds.), Handbook of educational psychology (p. 63-84). Macmillan Library Reference Usa; Prentice Hall International.

Gulloteaux, M., J., \& Dörnyei, Z. (2008). Motivating language learners: A classroom oriented investigation of the effects of motivational strategies on student motivation. TESOL Quarterly, 42, 55-77. https://doi.org/10.1002/j.1545-7249.2008.tb00207X

Harmer, J. (2008). How to sustain motivation in the classroom. Retrieved from http://www.geteenglishlessons.com

Hussain, D. (2018). Motivating English as a Foreign Language (EFL) Adult Learners: Challenges to Prepare Them for Future and Job Market. International Research Journal of Arts and Humanities, 46(46), 121-147.

Kassing, R. B. (2011). Perceptions of Motivational Teaching Strategies in an EFL Classroom: The Case of a Class in a Private University in Indonesia. Victoria University of Wellington.

Lai, E. (2011). Motivation: A literature review. Research Report, Pearson.

Mahadi, T., \& Jafari, S. (2012). Motivation, Its Types, and Its Impacts in Language Learning. International Journal of Business and Social Science, 3(24), 230-235

Mart, C., T. (2011). How to Sustain Students' Motivation in a Learning Environment. Erbil, Iraq: Ishik University.

Moskovsky, C., \& Alrabai, F. (2009). Intrinsic motivation in Saudi learners of English as a foreign language. The Open Applied Linguistics Journal, 2, 1-10. DOI: $\underline{10.2174 / 1874913500902010001}$

Nhem, D. (2019). Language Learning Strategies: A Comparative Study of Young and Adolescent Cambodian Learners. International Journal of Language and Literary Studies, 1(2) DOI: https://doi.org/10.36892/ijlls.v1i2.43 
Rayan, M., \& Deci, E. (2000). Intrinsic and extrinsic motivation: Classic definitions and new directions. Contemporary Educational Psychology, 25, 54-67. https://doi.org/10.1006/ceps.1999.1020

Ribas, F. c. (2009). The role of self-concepts in students' motivation in the Brazilian EFL context. Universidade Federal de UberlândiaLinguagem \& Ensino, Pelotas, 12(2), 463-486

Shousha, A. (2018). Motivational strategies and student motivation in an EFL Saudi context. International Journal of English Language Education, 6(1), 20-44. DOI:10.5296/ijele.v6i1.12535

Sun, Z. (2010). Language Teaching Materials and Learner Motivation. Journal of Language Teaching and Research, 1(6), 889-892. DOI:10.4304/j1tr.1.6.889-892

Svobodova, L. (2015). Factors affecting English language learning motivation of students of upper secondary school. Thesis Dissertation. Brno: Masaryk University. https://is.muni.cz/th/s4ddj/Diploma_Thesis_Svobodova.pdf

Wu, W., Yen, L., Marek, M. (2011). Using online EFL interaction to increase confidence, motivation, and ability. Educational Technology \& Society 14(3), 118129.https://www.jstor.org/stable/jeductechsoci.14.3.118

Wu, W., \& Wu, P. (2008). Creating an authentic EFL learning environment to enhance student motivation to study English. Asian EFL Journal, 10(4), 211-226. Retrieved from www.asian-efl- journal.com/December_2008_EBook.pdf.

\section{AUTHOR'S BIO:}

Dr. Seham Elashhab has a Ph.D. in Applied Linguistics from University of Ottawa, Canada. She has many years of English teaching experiences. Her research capabilities can be seen in several published papers in Applied Linguistics employing recent theories and approaches in the fields. Her research interests include all aspects of language teaching and learning as well as teacher development and training. She presented her work and conducted workshops in several conferences in various countries. She has been an active member in Accreditation Committee and Recruitment Committee of English Language Centre among others at Umm Al-Qura University. 